about which plant and animal facts may be grouped in a genetic manner; that variation, heredity, ontogeny, phylogeny, and environmental relations are all susceptible of dynamic treatment; and that on this basis there will result a new biology. Such an advance in point of view cannot of course be brought about in a year, but fortunate will be those who can contribute toward its development.

\title{
THE RELATION OF THE SCIENCES IN THE HIGH SCHOOL.
}

By H. R. LinvilLe, Jamaica High School, New York.

A history of the origin of secondary schools would be interesting in showing the process of the accumulation of subjects from the lower years of the college course. One can truly say that the high schools have been produced by the continued insistence of the college on the preparation of students in an increasing number of subjects which were college subjects.

The colleges have "passed on" work that they have chosen not to do, until the high school course increasing from one to four years is now so full that sharp competition has developed between the strbjects. There was a time in the history of high schools when mathematics, ancient languages and general history just about took up the energy of the pupils, but when the English and other modern languages, ancient, mediaeval and American history and the sciences, came to claim a portion of the pupils' time, competition was inevitable.

Some of the competition, especially that which threatens between the sciences in the high school course of study, is liable to prove extremely wasteful. There are four (or five) sciences which in relation to the competition for being credited by colleges are striving for a place in the third or fourth year of the course. It is probable that nowhere in the country is there a high school curricultum established that has a science course arranged with reference to the logical relation of the sciences. Usually physics and chemistry have the third and fourth years, and biology and physiography take the first and second years or struggle precariously with the better established sciences for a place in the later years.

*Aostract of an address to the Pacific coast Association of Physics and Chemistry Teachers, Summer Meeting, July 25, 1908. 
Teachers of science have it in their power to contribute materially to the saving of educational energy in certain important ways. First, they can demonstrate to the people that the study of the facts and principles of the branches of natural science are necessary to the comprehension of man's environment. If the necessity of knowing the environment could be impressed on the minds of people, every high school would teach the sciences as a matter of course. The second point that might be made by teachers is that there is a unity in the sciences which can be brought out by discovering and expressing the logic contained therein. There are fundamental facts and principles upon which the great generalizations are based.

When the thought of teachers is directed toward finding out where their science stands in relation to others, there will be less striving for the "best" years in the high school course. The great tsefulness of the sciences in general education will then become apparent.

\section{A LETTER.}

Minneapolis, Minn., Nov. 4, 1908.

Editor School Science ANd Mathematros:-

As I am a teacher of botany I am particularly pleased with the turn taken in the November number against the teaching of biology as a single science. In october $I$ thought we were going back into the dark ages. The idea of any one thinking that there is not enough of botany of practical interest to fill two semesters! I could use several years to adrantage.

Very truly yours,

(MIss) EloIse BoTter.

The tin question is a serious one for Russia. At the present moment, with the final stopping of the Pitteiranti tin-smelting works, this industry becomes completely suppressed in Russia, and that just at a time when tin is getting so valuable. The quantity of tin imported into Russia in 1904 was 301,000 poods of the value of $5,730,000$ rubles. Therefore it was most desirable that a tin industry should be a feature in Russia. At the Pitkransk deposits such would not be possible, for the tin there is only obtainatble along with other useful minerais in very small quantities. Therefore very serious attention should be paid to the tin deposits of the Transbaikal region on the Asian river, which but now have been sufficiently prospected, and in both quantity and quality are hardly surpassed by any known tin deposits. 